\title{
EFFECT OF WORK ENVIRONMENT, LEADERSHIP, COMPENSATION AND EMPLOYMENT TRAINING TO EMPLOYEE INVOLVEMENT
}

\author{
Antony Sentoso \\ Fakultas Ekonomi, Universitas Internasional Batam, Sei Ladi Jl. Gajah Mada Baloi Permai \\ Antony.Sentoso@gmail.com
}

\begin{abstract}
This study was conducted with the aim to determine the effect of the work environment, leadership, compensation and work training variables on employee involvement variables in star hotels in Batam. This research was conducted using a survey method through a questionnaire to 380 respondents, namely employees of five-star hotels in Batam. After being distributed directly to respondents, the questionnaire was collected and managed to get 340 questionnaires filled out completely and then the authors tested the regression data using the SPSS program. From the results of data processing with SPSS it is known that there is a relationship in all variables studied. Based on the results of this study, the relationship between work environment variables, leadership, compensation and work training in employee attachment variables is known, so it is expected that star hotel management can pay attention to the variables studied earlier and manage employee attachments as one of the added values and advantages of the hotel.
\end{abstract}

Keywords: leadership, working environment, compensation, training and employee engagement.

\section{PRELIMINARY}

Batam is one of the leading industrial cities in Indonesia, and is also one of the main entrances for the influx of foreign and domestic tourists. Batam is the main gate for foreign tourists (tourists) in the Riau Islands. In 2017, as many as 1.5 million foreign tourists entered through the port in Batam. A large portion of Batam $72.5 \%$ of the total 2.1 million foreign tourists visiting the Riau Islands. Globally, tourist arrivals are growing very well and the potential of tourist visits must be optimized by the local government and tourism industry managers in Batam. This is expected to be able to support economic growth in Batam, which has declined slightly due to the reduced number of industrial activities in manufacturing, fabrication and shipping industries (www.bpbatam.go.id).

The number of 2017 foreign tourists visiting the Riau Islands in general increased by $8.04 \%$. The increase was supported by a large current of 1.1 million Singaporean tourists. The fast pace of tourism is also positive for regional income cash. The tourism sector is claimed to generate regional authentic revenues worth IDR 4.8 trillion. A larger tourism sector growth target is also being set by the regional government in Batam now. The number of foreign tourists visiting the future is expected to reach 2.25 million in 2018 (www.bpbatam.go.id).

To be able to harmonize the development of tourism in Batam, the sector in the hotel industry must be able to support by providing accommodation facilities that can increase the level of foreign tourists as well as domestic tourists. Hotel is a type of accommodation service that provides lodging facilities and services as well as other public services that stay for a while. Hotel services are managed commercially or to obtain maximum profit profit by minimizing expenses but still prioritizing the best service for customers. In hotel activities that sell services, services from employees are really needed in order to compete with other five-star hotels, therefore the hotel management must be able to empower its 
employees and increase commitment to the hotel where they work so that the hotel can improve hotel performance in general (www. bps.go.id).

For companies engaged in services such as hotels, optimal services are needed to maintain the loyalty of customers who visit. The optimal services provided are not just serving, but efforts are made to build a mutually beneficial long-term cooperative relationship. With the continued increase in the amount of tourism, the number of hotels as a means of accommodation is also needed to support tourism activities. Based on the data, hotel growth in Batam City continues to increase every year, namely in 2013 there were 170 hotels, in 2014 there were 176 hotels, in 2015 there were 184 hotels, and in 2016 there were 190 hotels (www.bpbatam.go.id).

Batam which is one of the gates of foreign tourists is able to contribute a large percentage of the total number of foreign tourists visiting Riau Islands Province, which is around 75.23 percent of the number of foreign tourists visiting 211,732 people. Meanwhile, when presented to the number of foreign tourists visiting nationally, the tourists visiting Batam reached around 15.38 percent of the total national tourist arrivals nationally, namely from the number of foreign tourists visiting Indonesia.

Employee engagement is generally defined as an employee's level of commitment and attachment to his organization and its values. When an employee feels attached to the company where he works, then he realizes his responsibility in business goals and motivates his colleagues for the success of organizational goals (Ologbo \& Sofian, 2013). The employee's positive attitude to his workplace and value system or referred to as the positive emotional relationship of an employee towards his work. Employees who are tied to their work will transcend their roles and duties very well. There are various factors that determine employees as employees who are bound. The concept has evolved by considering various behaviors that are positively exhibited by productive employees.

Work environment is a condition that exists in the workplace both physical and non-physical which also influences employees in carrying out their work and the atmosphere felt by employees in their organizations relating to the attitudes and actions of colleagues and leaders as well as the work climate will affect employees' attachment to the company.

\section{RESEARCH METHOD}

This research is categorized as a basic research that has the aim of developing a theory, where the theories discussed in this study are only used for the benefit of the academic environment (Indriantoro \& Supomo, 2012). This research was compiled into a scientific work that can contribute to the development of science and also this research is one of the requirements in obtaining a degree in economics. However, when viewed from the side of the problem, this study is included in the comparative causal research which is a type of research with a problem in the form of a causal relationship between four independent variables namely leadership, work environment, compensation and work training on employee engagement as a dependent variable (Indriantoro \& Supomo, 2012).

The population in this study were 2,820 employees from 18 four star classification hotels located in Batam (www.phrionline.com). Based on Krejcie Morgan's table, with a population of 2,820, the minimum sample needed in this study amounted to 338 respondents. But as an anticipation if there are questionnaires that are not returned or not filled in completely, the authors distribute 380 questionnaires to respondents, namely employees of five 
four-star hotels that are the object of research. Hotel employees were chosen as the object of research because the hotel sector is one of Batam's mainstays in getting regional income that is quite important so that the results of this study are expected to be able to provide benefits to many parties involved. So that the hotel can be more advanced, it requires employees who are able to work optimally and have a good attachment to the hotel where they work. Here the authors present the number of employees of four-star hotels based on sources obtained from the Indonesian Hotel and Restaurant Association (PHRI) Batam.

Author distributed 380 sets of questionnaires to employees of 5 star-rated hotels in Batam that were sampled in this study. There were 340 questionnaires returned and 40 were not returned. The number of respondents based on gender where there are 154 male respondents and 186 female respondents. It can be said that most of the respondents are women. Based on the age of respondents where there are 144 respondents aged 18-25 years, 96 respondents aged 26-30 years, 69 respondents aged 31-39 years and there are around 31 respondents aged over 39 years. Based on his last level of education. There are 169 respondents who have a high school or vocational level, 85 respondents who have a diploma level, then there are 67 respondents with a Bachelor's level and 19 other educated respondents. years, 132 respondents who have worked for 4-6 years, and there are 67 respondents with tenure of more than 6 years. The majority of respondents work in hotels now for 1-3 years. Based on the total income of respondents in a month, it is known that there are 181 respondents with income of Rp. 3.5 - 4.5 million per month, 93 respondents with income of Rp. 4.6 - 6 million per month and there are 66 respondents with income greater than $\mathrm{Rp}$. 6 million per month. So it can be concluded that the majority of respondents have incomes between Rp. $3.5-4.5$ million per month.

\section{RESULT AND DISCUSSION}

To find out whether there are distorted data in the questionnaire distributed to respondents, the authors conducted an outlier test, which based on the results of this test of 340 respondents, no z-score was found that was smaller than -3 and or greater than 3. So that all respondents can be included in the next test because it is considered reasonable in providing answers to the questionnaire distributed. Data deemed to be deviating from the average will be discarded and will not be tested again (Ghozali, 2011).

Based on the results of the validity shown above for the 25 questions in the questionnaire there is 1 question that is not valid, namely leadership 5 with a validity value of 0.430 , so that the question cannot be included in the subsequent data processing. Validity test will be concluded valid if it has a factor loading value above 0.6 (Ghozali, 2011). After conducting the reliability test, Cronbach alphanumeric values obtained from all variables indicate that all variables exceed the value of the consistency limit of 0.6 (Ghozali, 2011) so that all variables used in this study are declared reliable.

Through the normality test it can be seen that the PPlot shows that the data has a normal distribution and spreads along the diagonal line, it is concluded that all regression models used in this study are appropriate because they meet the normality assumption. Multicollinearity test results on the independent variables found no value that indicates the value of tolerance below 0.10 , which means there is no correlation between independent variables.

Heterokedastisitas test results with glacial test of leadership variables, work environment, compensation and work training on employee engagement. 
Independent and dependent variables are normally distributed with values above 0.05 , it can be concluded that heterocedasticity does not occur.

The $\mathrm{F}$ test is used to show whether all independent variables have a joint influence on the dependent variable. $\mathrm{F}$ test is done by looking at the significance value. Probability values less than 0.05 , so the regression model can be used to predict the dependent variable (Ghozali, 2001). F test results obtained a probability level of 0,000 . The probability level of 0,000 is more than 0.05 so that the regression model can be used to predict or measure organizational commitment variables as the dependent variable.

Based on the results of the $t$ test it was found that the significance value of $\mathrm{H} 1$ was 0.024 and the beta value was 0.116 , it was concluded that there was a significant relationship and influence between the work environment variables on employee attachment to starred hotel employees in Batam. These findings indicate that the work environment in a hotel has a significant effect on employee engagement in the hotel where he works. Based on the $t$ test results it is known that the significance value of $\mathrm{H} 2$ is 0.021 and beta value is 0.151 so it can be concluded that there is a significant relationship between leadership and employee engagement. The results of this study indicate that the leadership style of superiors will affect the level of employee attachment to the hotel where he works. Based on the $t$ test it is known that the significance value of $\mathrm{H} 3$ is 0.001 and the beta value is 0.180 so it can be said that the level of compensation given to company employees in the hotel sector has a significant impact on employee attachment to the hotel. Based on the results of the $t$ test showed that the significance value of $\mathrm{H} 4$ was 0,000 and beta value was 0.378 so that it can The conclusion was drawn that in this study the job training held by the company had a significant influence on the level of engagement with starred hotel employees.

From the test results of the coefficient of determination (R2) of 0.492 , it is known that the large independent variable has the ability of $49.2 \%$ in explaining the relationship with the dependent variable. But there are $51.8 \%$ of other factors explained by other variables not examined in this study such as work culture and teamwork (Ravikumar, 2013). If the work culture of an organization is going well and there is good teamwork for all members of the organization will encourage increased sense of belonging for employees at the company where they work which will also increase the level of employee engagement.

\section{CONCLUSION}

The work environment provides a significant role in increasing the level of work engagement of starred hotel employees. Comfortable and attractive financial design and the preparation of appropriate work equipment will facilitate the work of employees and contribute to the engagement of employees of star-rated hotels. A clean and comfortable work space, accompanied by adequate indoor lighting, good air circulation to the availability of work equipment will further increase the attachment of starred hotel employees to their place of work.

Leadership also has a significant positive effect on the level of work engagement of starred hotel employees. The leader is one of the factors that play a role in increasing employee engagement in the hotel where he works.

Compensation has a positive role in increasing employee attachment to the company, where employee satisfaction with the provision of compensation and appropriate rewards also contribute to an increase in employee engagement and work better. Compensation policies can be carried out by providing incentives or 
benefits related to achieving work targets such as the number of guests staying and facilities used by guests.

Job training programs held by the company for employees have a very important role in increasing employee attachment to the hotel where they work. Employees who are given training according to work needs will try to improve performance and try to provide the best work results. Along with the development of a sense of belonging to the organization will have a significant impact on increasing work engagement.

\section{GRATITUDE}

Author say the biggest gratitude to Universitas Internasional Batam that provides opportunities to author. Author also give big thanks to the faculty of economics for continuing encourage author to be enthusiastic in completing this research, last but not least author thankful because of the families that encouraging author to have time to write.

\section{REFERENCES}

Alvi, K.H., Khan, M.A., Ahmed, A.A., dan Zulfiqar, M (2014) A Study of Employee Compensation and Employee Job Engagement on Banks of Lahore, Pakistan. Science International Journal (Lahore), 26 (5), 2411-2414 (2014)

Anitha J. (2014) Determinants of Employee Engagement and Their Impact on Employee Performance. International Journal of Productivity and Performance Management Vol. 63 No. 3, 2014

Azeem, M.F., Rubina dan Paracha, A.T (2013) Connecting Training and Development with Employee Engagement: How does it Matter? World Applied Sciences Journal 28 (5): 696-703, 2013

Bedarkar, M dan Pandita, D (2014) A Study on the Drivers of Employee Engagement Impacting Employee Performance. Social and Behavioral Sciences 133 (2014) 106 115

Ghozali, I (2011). Aplikasi Analisis Multivariate dengan Program SPSS, Badan Penerbit Universitas Diponegoro, Semarang
Hair, J.F., Black, W.C., Babin, B.J., dan Anderson, R.E. (2010). Multivariate Data Analysis. Seventh Edition. Prentice Hall, Upper Saddle River, New Jersey.

Indriantoro, N \& Supomo, B (2012). Metedologi Penelitian Bisnis. Yogyakarta : Edisi Pertama, Penerbit BPFE.

Khuong, M.N. dan Yen, N.H (2014) The Effects of Leadership Styles and Sociability Trait Emotional Intelligence on Employee Engagement - A Study in Binh Duong City, Vietnam. International Journal of Current Research and Academic Review Vol. 2 NO. 1 (January, 2014) pp. 121-136

Lai, P.Y., Lee, J.S., Lim, Y.X., Yeoh, R.G., dan Mohsin, F.H (2015) The Linkage between Training and Development and CoWorker Support towards Employee Engagement in Hotel Industry. International Journal of Scientific and Research Publications, Volume 5, Issue 5, May 2015

Manuel, F.D (2014) The Effect of Training and Development on Employee Engagement. World Review of Business Research Vol. 2. No. 5.

Naidoo, P dan Martins, N (2014) Investigating the Relationship between Organizational Culture and Work Engagement. Problems and Perspectives in Management, Volume 12, Issue 4, 2014

Ologbo, A.C dan Sofian, S (2013) Individual and Organizational Factors of Employee Engagement on Employee Work Outcomes. International Journal of Business and Behavioral Sciences Vol. 3, No.3; March 2013

Ravikumar, T (2013) Study on Impact of Teamwork, Work Culture, Leadership and Compensation on Engagement Level of Employees in MSMES in India. International Journal of Advanced Research in Management and Social Sciences Vol. 2 No. 8 August 2013

Suharti, L dan Suliyanto, D (2012) The Effects of Organizational Culture and Leadership Style toward Employee Engagement and Their Impacts toward Employee Loyalty. World Review of Business Research Vol. 2. No. 5. September 2012. Pp. 128 - 139

Sundaray, B.K (2011) Employee Engagement: A Driver of Organizational Effectiveness. European Journal of Business and Management Vol 3, No.8, 2011

Swathi, S (2013) Effecting Employee Engagement Factors. International Journal of Scientific and Research Publications, Volume 3, Issue 8, August 2013 